\title{
Effect of blockade of nitric oxide synthesis on the renin secretory response to frusemide in conscious rabbits
}

\author{
Ian A. REID and Lance CHOU \\ Department of Physiology, University of California, San Francisco, San Francisco, California, \\ U.S.A.
}

(Received 6 June 1994/23 January 1995; accepted 14 February 1995)

\begin{abstract}
1. The enzyme nitric oxide synthase is present in the macula densa and may participate in the control of renin secretion by the adjacent juxtaglomerular cells. In the present study, we investigated the effect of inhibiting nitric oxide synthase on the renin secretory response to frusemide, which stimulates renin secretion by blocking $\mathrm{Na}^{+}-\mathrm{K}^{+}-2 \mathrm{Cl}^{-}$co-transport in the macula densa.
\end{abstract}

2. Injection of frusemide in 12 conscious rabbits elicited a transient increase in mean arterial pressure from $84 \pm 2$ to $92 \pm 3 \mathrm{mmHg}$ at $5 \mathrm{~min}(P<0.01)$ and a sustained increase in heart rate from $246 \pm 6$ to $281 \pm 10$ beats $/ \mathrm{min}$ at $45 \mathrm{~min}(P<0.01)$. Plasma renin activity increased from $8.0 \pm 1.2$ to $14.3 \pm 1.8$, $12.4 \pm 1.6$ and $11.6 \pm 1.5 \mathrm{pmol}^{-1} \mathrm{~h}^{-1} \mathrm{ml}^{-1}$ at 15,30 and $45 \mathrm{~min}$ respectively $(P<0.01)$. There were no changes in plasma sodium and potassium concentrations or osmolality.

3. Inhibition of nitric oxide synthase with $N^{\mathrm{G}}$-nitro-Larginine methyl ester increased mean arterial pressure by $9 \mathrm{mmHg}$, decreased heart rate and plasma renin activity, and markedly suppressed the renin response to frusemide (from $4.6 \pm 0.7$ to $7.6 \pm 1.7$,

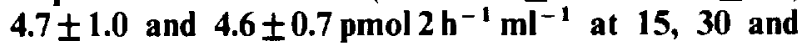
$45 \mathrm{~min}$ respectively). By contrast, infusion of an equipressor dose of phenylephrine did not suppress the renin response to frusemide.

4. Histochemical studies with the NADPH diaphorase technique confirmed the presence of nitric oxide synthase in the macula densa, and suggested that enzyme activity is increased by treatment with frusemide.

5. These results are consistent with a role for the Larginine-nitric oxide pathway in the modulation of renin secretion by the macula densa.

\section{INTRODUCTION}

Anatomical and functional studies have established that the macula densa plays an important role in the regulation of renin secretion [1-5]. Specifically, there is evidence that the macula densa functions as a sodium/chloride sensor by a mechanism involving an $\mathrm{Na}^{+}-\mathrm{K}^{+}-2 \mathrm{Cl}^{-}$co-transporter in the luminal membrane of the macula densa cells [5-7]. Alterations in $\mathrm{Na}^{+}-\mathrm{K}^{+}-2 \mathrm{Cl}^{-}$co-transport result in inverse changes in renin secretion by the adjacent juxtaglomerular cells [8].

One of the least understood aspects of this macula densa control of renin secretion is how the cells of the macula densa communicate with the juxtaglomerular cells. Several mediators have been proposed, including adenosine and prostacyclin [5, 9 , 10]. Nitric oxide may also play a role. This proposal is based primarily on the findings that the macula densa contains a high concentration of the enzyme nitric oxide synthase [11-13] and that arginine analogues which inhibit nitric oxide synthase alter the rate of renin secretion [14-19].

The aim of the present investigation was to test the hypothesis that the L-arginine-nitric oxide pathway participates in the control of renin secretion by the macula densa. Experiments were performed in conscious rabbits to determine if inhibition of nitric oxide synthesis alters the renin secretory response to frusemide, a diuretic that stimulates renin secretion by, at least in part, inhibiting $\mathrm{Na}^{+}-\mathrm{K}^{+}-2 \mathrm{Cl}^{-}$cotransport in the macula densa $[20,21]$. In addition, the NADPH diaphorase histochemical technique was used to determine if acute administration of frusemide alters nitric oxide synthase activity in the macula densa.

\section{METHODS}

The experiments were performed on male New Zealand White rabbits weighing $2.5-3.5 \mathrm{~kg}$ (Nitabell Rabbitry, Hayward, CA, U.S.A.). The rabbits were housed in separate cages in a $12 \mathrm{~h}$ light-cycled and temperature-controlled room. They were fed a commercial diet (Purina rabbit chow, Ralston-Purina, St. Louis, MO, U.S.A.) and were provided with water ad libitum. Surgical and experimental procedures were approved by the University of California, San Francisco Committee on Animal Research.

\section{Surgical preparation}

Surgical procedures were performed under aseptic

Key words: frusemide, nitric oxide, $N G$-nitro-L-arginine methyl ester, macula densa, renin release.

Abbreviations: HR, heart rate; L-NAME, NG-nitro-L-arginine methyl ester; MAP, mean arcerial pressure; PRA, plasma renin activity.

Correspondence: Dr lan A. Reid, Department of Physiology. University of California. San Francisco. San Francisco, CA 94143-0444, U.S.A. 
conditions during anaesthesia with intramuscular ketamine $(35-50 \mathrm{mg} / \mathrm{kg}$; Parke-Davis, Morris Plains, NJ, U.S.A.) and xylazine $(5-10 \mathrm{mg} / \mathrm{kg}$; Lloyd Laboratories, Shenandoah, IA, U.S.A.). A catheter consisting of $10 \mathrm{~cm}$ of medical-grade Silastic $10.76 \mathrm{~mm}$ inner diameter, $1.65 \mathrm{~mm}$ outer diameter; Dow-Corning Corp., Midland, MI, U.S.A.) connected to PE60 tubing was inserted into a femoral artery and advanced into the aorta to a point distal to the kidneys. Two Tygon catheters $(0.76 \mathrm{~mm}$ inner diameter, $1.27 \mathrm{~mm}$ outer diameter) were inserted into a jugular vein and positioned near the heart. The three catheters were led subcutaneously to a point between the scapulae, where they emerged through a small skin incision, and were protected in a pocket of a nylon mesh jacket. The rabbits were allowed to recover for at least 3 days after surgery, during which time they were treated with intravenous ampicillin $(10 \mathrm{mg} /$ day; Sigma, Chemical Co., St Louis, MO, U.S.A.). The catheters were flushed with sterile heparinized isotonic saline $(100 \mathrm{units} / \mathrm{ml})$ at least every other day. During the recovery period, the rabbits were brought to the laboratory and accustomed to the experimental environment.

\section{Experimental protocols}

On the day of an experiment, a rabbit was brought to the laboratory, where it rested comfortably in a partly covered cage. Arterial blood pressure and heart rate were continuously monitored using a pressure transducer (Cobe Laboratories, Lakewood, CO, U.S.A.) and a custom-built cardiovascular analyser. The cardiovascular data were simultaneously recorded on a Grass polygraph, and digitized, stored and analysed using a PDP 11/ 23 + computer (Digital Equipment Corporation, Maynard, MA, U.S.A.). Blood samples (volume= $1.2 \mathrm{ml}$ ) for analysis were collected from the femoral arterial catheter and replaced with an equal volume of sterile isotonic $\mathrm{NaCl}$. We have previously observed that the volume of blood removed during the course of these experiments does not change the haematocrit. Experiments were begun when blood pressure and heart rate had remained stable at their basal values for at least $15 \mathrm{~min}$. The experiments were performed according to the following protocols.

Effect of inhibition of nitric oxide synthesis on the renin and cardiovascular responses to frusemide. In 12 rabbits, blood pressure and heart rate were monitored during a $15-\mathrm{min}$ control period, at the end of which a blood sample was collected. An intravenous infusion of $0.9 \%$ saline at $0.02 \mathrm{ml} / \mathrm{min}$ was then started and continued for the duration of the experiment. Fifteen minutes after the start of the saline infusion, another blood sample was collected. Frusemide (American Regent Laboratories, Shirley, NY, U.S.A.) was then injected intravenously in a single dose of $2.0 \mathrm{mg} / \mathrm{kg}$. Blood samples were collected 15,30 , and $45 \mathrm{~min}$ after frusemide administration. This procedure was repeated in the same rabbits on the following day, but the saline infusion was replaced with an intravenous infusion of the nitric oxide synthase inhibitor $N^{\mathrm{G}}$-nitro-L-arginine methyl ester hydrochloride (L-NAME, Sigma) [22, 23] at $0.5 \mathrm{mg} \mathrm{min}^{-1} \mathrm{~kg}^{-1}$. On the third day, the effect of frusemide in the presence of isotonic saline was tested again.

Effect of phenylephrine on the renin and cardiovascular responses to frusemide. The aim of this experiment was to investigate the possibility that LNAME might alter the renin response to frusemide by increasing blood pressure. In nine rabbits, the effects of frusemide were tested as described in the protocol above, but the L-NAME infusion on day 2 was replaced with an intravenous infusion of phenylephrine (Neo-Synephrine, Winthrop, NY, U.S.A.). The dose of phenylephrine was adjusted between 0.5 and $2.0 \mu \mathrm{g} \mathrm{min}^{-1} \mathrm{~kg}^{-1}$ in order to produce the same increase in blood pressure as that produced by L-NAME.

NADPH diaphorase histochemistry. Rabbits received an intravenous injection of isotonic saline $(2 \mathrm{ml}, n=3)$ or frusemide $(10 \mathrm{mg} / \mathrm{kg}, n=3)$. Thirty minutes later the rabbits were anaesthetized with sodium pentobarbital $(30 \mathrm{mg} / \mathrm{kg})$ and the kidneys rapidly removed. Blocks of renal cortex were fixed for $4 \mathrm{~h}$ in phosphate buffer ( $\mathrm{pH} 8.0$ ) containing $2 \%$ formaldehyde and $0.002 \%$ picric acid, immersed in $15 \%$ sucrose for $24 \mathrm{~h}$ and frozen. Tissue sections of $7 \mu \mathrm{m}$ were cut in a cryostat, placed on charged glass slides, and dried. The sections were incubated at $37^{\prime} \mathrm{C}$ for $60-90 \mathrm{~min}$ in phosphate buffer (pH 8.0) containing NADPH $(1 \mathrm{mg} / \mathrm{ml})$, nitroblue tetrazolium $(0.1 \mathrm{mg} / \mathrm{ml})$ and $0.2 \%$ Triton $\mathrm{X}-100$. The sections were then rinsed, mounted in glycerol and examined by light microscopy.

\section{Analytical methods}

Plasma renin activity (PRA) was measured using a radioimmunoassay for angiotensin $I$ and expressed as pmol of angiotensin I generated per $\mathrm{ml}$ of plasma during a 2-h incubation at $37^{\circ} \mathrm{C}$ and $\mathrm{pH} 6.5$ $\left(\mathrm{pmol} 2 \mathrm{~h}^{-1} \mathrm{ml}^{-1}\right.$ ) [24]. Plasma sodium and potassium concentrations were measured by flame photometry and plasma osmolality by freezing point depression.

\section{Statistical analysis}

Results are expressed as the means \pm SEM. Data were analysed using analysis of variance for repeated measures followed by the Neuman-Keuls or Dunnett test [25]. Changes were considered to be statistically significant when $P<0.05$.

\section{RESULTS}

Effect of inhibition of nitric oxide synthesis on the renin and cardiovascular responses to frusemide

The effects of frusemide and L-NAME on blood pressure, heart rate and plasma renin activity are 

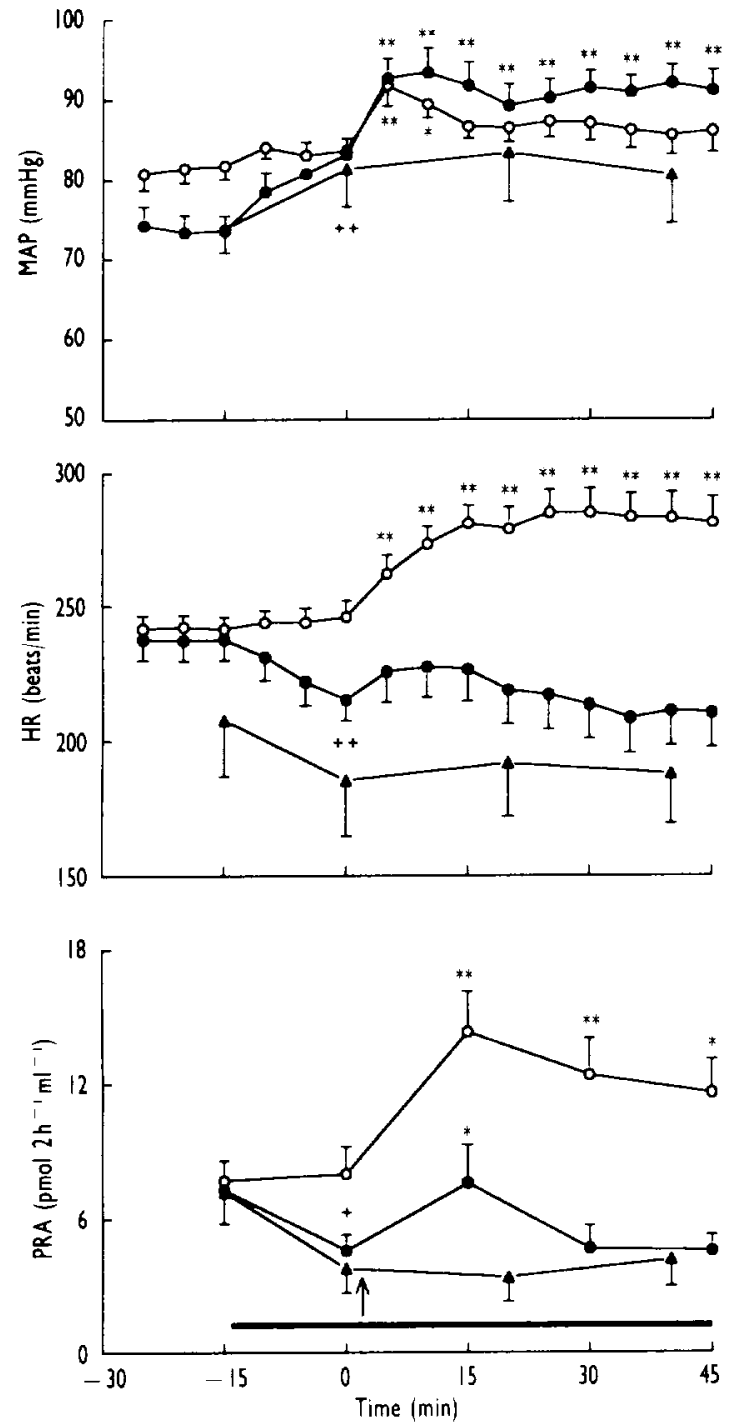

Fig. I. Effects of frusemide on mean arterial pressure (MAP), heart rate (HR) and plasma renin activity (PRA) during infusion of saline vehicle or L-NAME. Infusion of L-NAME or saline was started immediately after completion of control measurements at ... 15 min and continued throughout the experiment as indicated by the horizontal bar. Frusemide was injected at 0 min as indicated by the arrow. Values represent the means \pm SEM of observations made in 12 rabbits. Previously reported data [14] showing the effects of L-NAME without frusemide are also shown. $+p<0.05,+p<0.01$ compared with -15 min value. ${ }^{*} p<0.05,{ }^{* *} p<$ 0.01 compared with $0 \mathrm{~min}$ value. $O$. Salineifrusemide: $O-N A M E$ ifrusemide; $\triangle$. L-NAMEisaline.

summarized in Fig. 1. Injection of frusemide elicited a transient increase in mean arterial pressure (MAP) from $84 \pm 2$ to $92 \pm 3 \mathrm{mmHg}$ at $5 \mathrm{~min}$ $(P<0.01)$, and increased heart rate $(\mathrm{HR})$ from $246 \pm 6$ to $281 \pm 10$ beats $/ \mathrm{min}$ at $45 \mathrm{~min}(P<0.01)$. PRA increased from $8.0 \pm 1.2$ to $14.3 \pm 1.8 \mathrm{pmol}^{2} \mathrm{~h}^{-1} \mathrm{ml}^{-1}$ $15 \mathrm{~min}$ after the injection and remained elevated for the next $30 \mathrm{~min}$. Administration of frusemide did not change plasma sodium $(142 \pm 0.4$ to $143 \pm$ $0.4 \mathrm{mmol} / \mathrm{l})$ or potassium $(4.2 \pm 0.1$ to $4.1 \pm 0.1$ $\mathrm{mmol} / 1)$ concentrations, or osmolality $(289 \pm 1$ to $288 \pm 1 \mathrm{mosmol} / \mathrm{kg} \mathrm{H}_{2} \mathrm{O}$ ). On the following day, infusion of $\mathrm{L}-\mathrm{NAME}$ increased MAP from $74 \pm 2$ to $83 \pm 2 \mathrm{mmHg}(P<0.01)$, decreased HR from $238 \pm 8$ to $215 \pm 8$ beats $/ \mathrm{min}(P<0.01)$ and decreased PRA

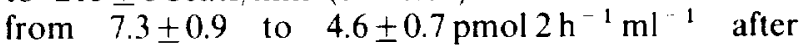
$15 \mathrm{~min}(P<0.01)$. L-NAME markedly reduced the renin response to subsequent administration of frusemide. Thus, while frusemide alone increased

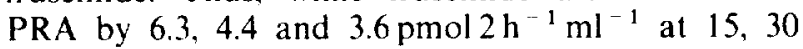
and $45 \mathrm{~min}$ respectively, frusemide in the presence of L-NAME increased it by only 3.0, 0.1 and $0 \mathrm{pmol} 2 \mathrm{~h}^{-1} \mathrm{ml}^{-1}$. Treatment with L-NAME also prolonged the pressor response to frusemide and inhibited the $H R$ response.

Previously reported data [14] showing the effects of L-NAME without frusemide are also shown in Fig. 1. It can be seen that the maximum cardiovascular and renin responses to this dose of L-NAME occur during the first $15 \mathrm{~min}$ of the L-NAME infusion.

Administration of frusemide on the third day produced changes in MAP $(83.4 \pm 4.9$ to $88.5 \pm$ $3.9 \mathrm{mmHg}$ at $5 \mathrm{~min})$, HR $(198 \pm 6$ to $257 \pm 11$ beats $\min$ at $45 \mathrm{~min})$ and PRA $(5.6 \pm 1.2$ to $12.4 \pm 3.8$ pmol $2 \mathrm{~h}^{-1} \mathrm{ml}{ }^{-1}$ at $15 \mathrm{~min}$ ) that were not significantly different from those on the first day.

\section{Effect of phenylephrine on the renin and cardiovascular responses to frusemide}

The effect of phenylephrine on the renin and cardiovascular responses to frusemide are summarized in Fig. 2. Frusemide alone increased PRA from $4.9 \pm 1.0$ to $9.3 \pm 1.3 \mathrm{pmol}^{2} \mathrm{~h}^{-1} \mathrm{ml}^{-1}$ at $15 \mathrm{~min}$ $(P<0.01)$. Infusion of phenylephrine increased MAP from $73 \pm 3$ to $82 \pm 4 \mathrm{mmHg}(P<0.01)$ (an increase identical to that produced by L-NAME) and decreased PRA from $5.1 \pm 0.7$ to $2.6 \pm$ $0.5 \mathrm{pmol}^{2} \mathrm{~h}^{1} \mathrm{ml}{ }^{1}(P<0.05)$. However, in contrast to L-NAME, phenylephrine did not reduce the subsequent PRA response to frusemide (to $7.3 \pm$ $1.9 \mathrm{pmol}^{2} \mathrm{~h}^{1} \mathrm{ml}{ }^{1}$ at $\left.15 \mathrm{~min}, P<0.05\right)$, although the response was more variable in the presence of phenylephrine. The $\mathrm{MAP}$ and $\mathrm{HR}$ responses to frusemide were also unaltered by phenylephrine.

\section{NADPH diaphorase histochemistry}

NADPH diaphorase staining was observed in macula densas of kidneys from control rabbits and from rabbits treated with frusemide. Representative sections of renal cortex from two control and two frusemide-treated rabbits are shown in Fig. 3. Staining of the macula densa was generally more intense in frusemide-treated rabbits than in control rabbits. However, quantitation of the staining intensity is required before firm conclusions can be made concerning the effect of frusemide. 

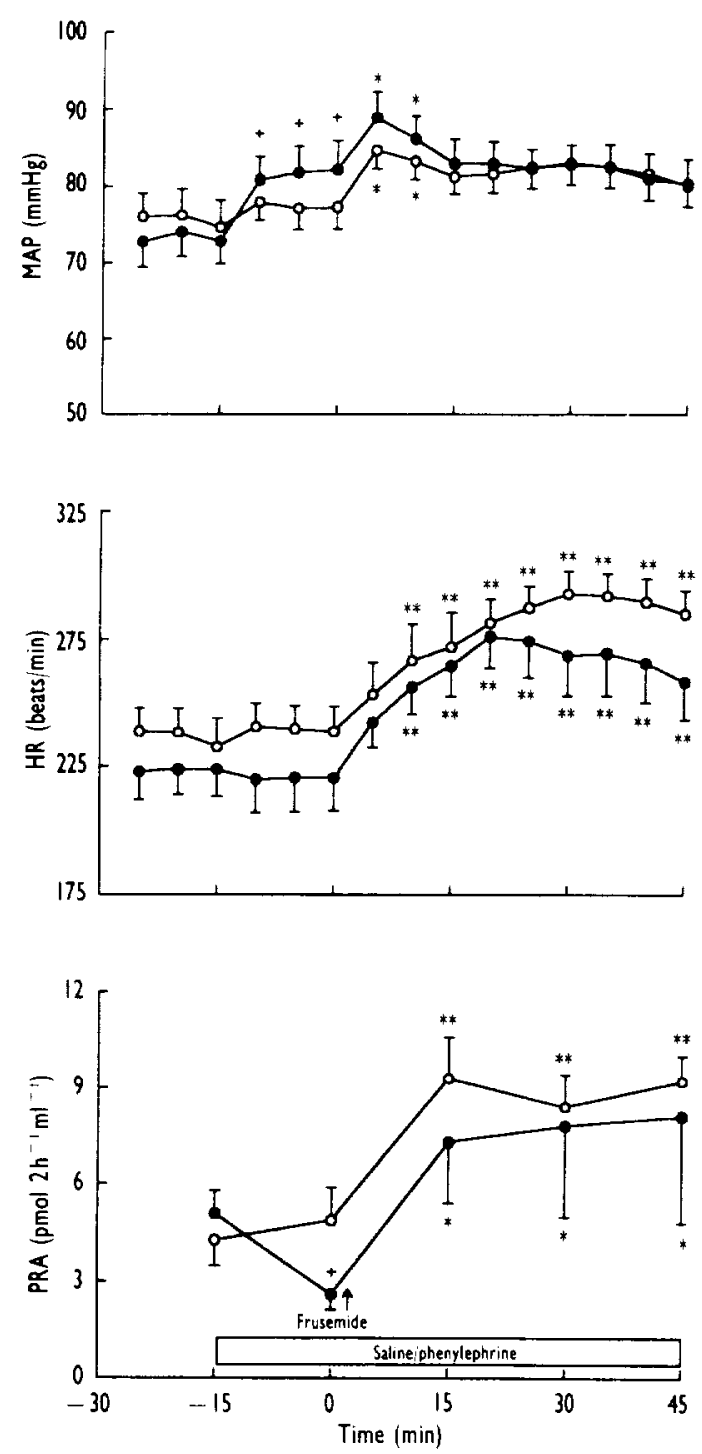

Fig. 2. Effects of frusemide on mean arterial pressure (MAP), heart rate (HR) and plasma renin activity (PRA) during infusion of saline vehicle $(O)$ or phenylephrine (O). Infusion of phenylephrine or saline was started immediately after completion of control measurements at $-15 \mathrm{~min}$ and continued throughout the experiment. Frusemide was injected at $0 \mathrm{~min}$. Values represent the means $\pm S E M$ of observations made in nine rabbits. $+p<0.05$ compared with -15 min value. ${ }^{*}<<0.05$, ${ }^{* * p}<0.01$ compared with $0 \mathrm{~min}$ value.

\section{DISCUSSION}

The aim of this investigation was to determine if nitric oxide participates in macula densa-mediated control of renin secretion. In order to do this, it was necessary to identify a stimulus to renin secretion that operates specifically through the macula densa mechanism. This is difficult because many stimuli which are believed to activate the macula densa mechanism, e.g. sodium deficiency, haemorrhage and decreased renal perfusion pressure, also activate the renal baroreceptor and/or extrarenal mechanisms controlling renin secretion $[1.2,4]$.
One exception is administration of frusemide. Although this diuretic has multiple and complex effects on renin secretion when administered chronically [2], it appears to stimulate renin secretion by a direct action on the macula densa when administered acutely $[21,26,27,30]$. Thus, in the present experiments, the maximum renin response to frusemide occurred at $15 \mathrm{~min}$, at which time volume depletion would have been insignificant. Other investigators have reported that frusemide increases renin secretion when urinary losses are prevented $[26,27]$. Blood pressure increased transiently following frusemide administration, and this would be expected to decrease, rather than increase, renin secretion $[1,2]$. Plasma sodium and potassium concentrations and osmolality did not change. Frusemide has been reported to increase renal sympathetic nerve activity in rats [28] and plasma noradrenaline concentration in dogs [29], but the renin secretory response to acute administration of frusemide is not blocked by $\beta$-adrenoceptor blockade $[27,30]$, suggesting that it is not mediated by the sympathetic nervous system. Moreover, in preliminary experiments we observed that frusemide does not increase renal sympathetic nerve activity in conscious rabbits ( $\mathrm{K}$. Kumagai and I. A. Reid, unpublished work). Finally, frusemide stimulates renin secretion by microdissected afferent arterioles with the macula densa attached, but not from microdissected afferent arterioles alone [21]. Thus, the stimulation of renin secretion by frusemide in the present study was probably mediated by the macula densa. Recent evidence indicates that this stimulation results from inhibition of $\mathrm{Na}^{+}-\mathrm{K}^{+}-2 \mathrm{Cl}^{-}$co-transport in the macula densa $[5-8,20]$.

It has been reported that the macula densa contains a high level of nitric oxide synthase as detected by immunocytochemistry and NADPH diaphorase histochemisty [11-13], and this was confirmed in the present study. Furthermore, it has been suggested that nitric oxide originating in the macula densa participates in the control of renin secretion [11, 12]; indeed, it may be an important chemical mediator between the macula densa and the juxtaglomerular cells. In order to test this possibility, we investigated the effect of inhibiting nitric oxide synthase on the renin response to frusemide. L-NAME decreased resting PRA and markedly suppressed the renin response to frusemide. Before L-NAME, there were significant increases in PRA 15, 30 and $45 \mathrm{~min}$ after frusemide; after L-NAME, there was only a small, transient increase at $15 \mathrm{~min}$.

It is important to note that L-NAME was administered systemically in the present study so that blockade of nitric oxide synthase was not limited to the kidney. Thus, the possibility must be considered that the inhibitory effect of L-NAME on the renin response to frusemide was a consequence of inhibition of extrarenal nitric oxide synthase, in particular 

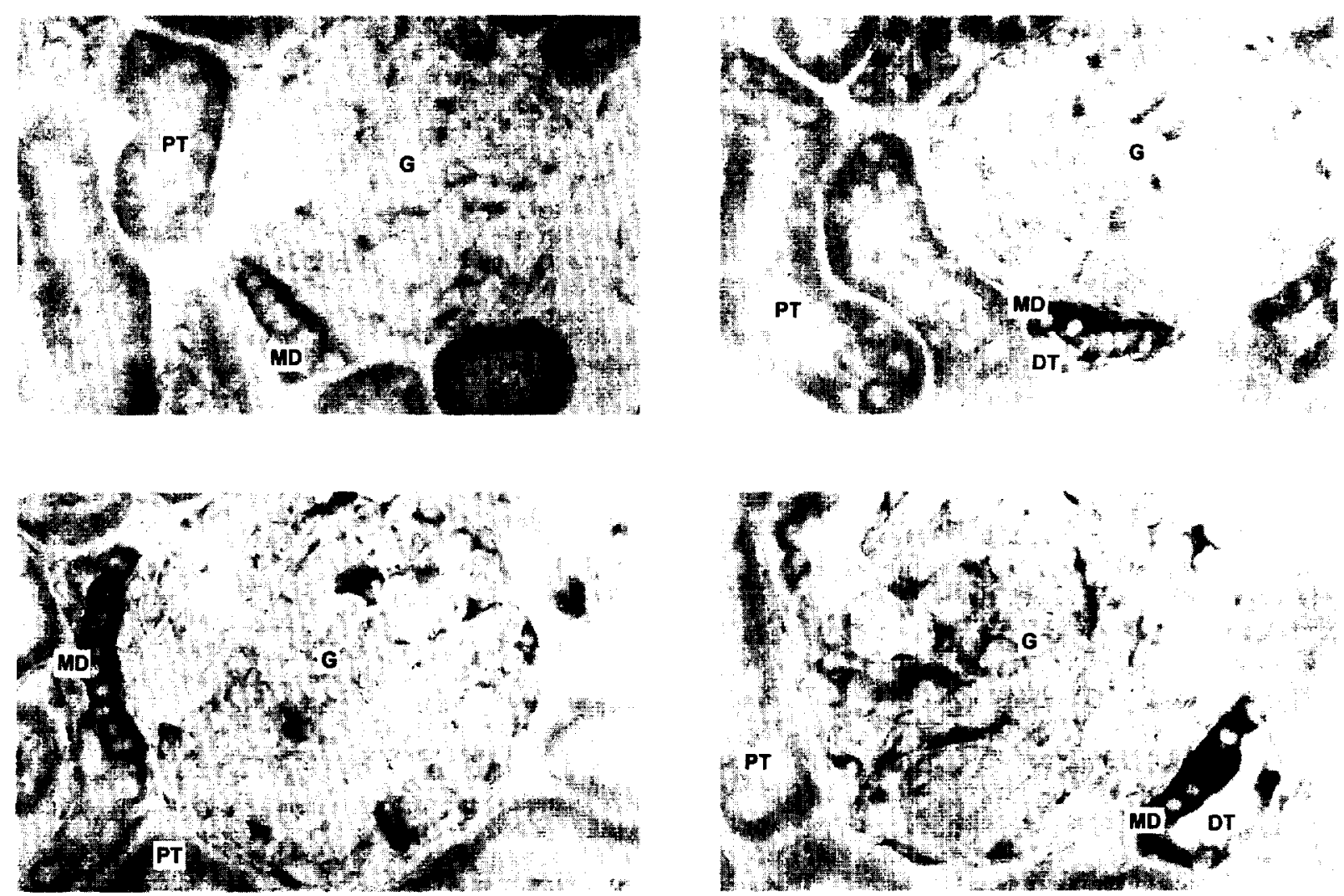

Fig. 3. NADPH histochemistry of sections of kidneys from two control rabbits (top) and two frusemide-treated rabbits (bottom). G, glomerulus; MD, macula densa: PT, proximal tubule; DT, distal tubule.

the increase in blood pressure. However, infusion of an equipressor dose of phenylephrine did not inhibit the renin response to frusemide, and it therefore seems reasonable to suggest that L-NAME inhibits the renin response to frusemide by blocking nitric oxide synthesis within the kidney. Nevertheless, it is difficult to rule out the systemic effects of blockade of nitric oxide synthesis, and additional studies with intrarenal infusion of L-NAME are needed to rest this proposal more directly.

How could nitric oxide translate changes in macula densa $\mathrm{Na}^{+}-\mathrm{K}^{+}-2 \mathrm{Cl}^{-}$transport into changes in renin secretion? Specifically, does $\mathrm{Na}^{+}-\mathrm{K}^{+}-2 \mathrm{Cl}$ transport affect macula densa nitric oxide synthase activity, and what effect does nitric oxide have on renin secretion? At present, there is no clear answer to either question, but the following is presented as a working hypotheșis. First, it is proposed that nitric oxide originating in the macula densa diffuses into the adjacent juxtaglomerular cells. Here it could increase cyclic GMP concentration, which in turn could stimulate renin secretion, possibly by decreasing the intracellular concentration of calcium $[4,31]$. In support of this proposal are reports that blockade of nitric oxide synthase decreases renal cyclic GMP levels [32] and inhibits renin secretion in vitro and in vivo [14-19]. Second, it is proposed that $\mathrm{Na}^{+}-\mathrm{K}^{+}-2 \mathrm{Cl}$ co-transport by the macula densa decreases calcium concentration in cells of the macula densa and, as a result, decreases nitric oxide synthase activity and nitric oxide formation. Blocking $\mathrm{Na}^{+}-\mathrm{K}^{+}-2 \mathrm{Cl}$ co-transport with frusemide would increase nitric oxide synthase activity (as the results of the present histochemical study suggest), resulting in an increase in renin secretion which would be prevented by L-NAME (as was observed in the present study). According to this scheme, it would be predicted that the renin response to a reduction in the delivery of sodium chloride to the macula densa would also be blocked by inhibition of nitric oxide synthase. Recent studies by $\mathrm{He}$ et al. [33] using a perfused juxtaglomerular apparatus preparation have shown this to be the case.

Several key questions concerning this hypothesis remain to be resolved. In particular, there is, to our knowledge, no direct evidence that $\mathrm{Na}^{+}-\mathrm{K}^{+}-2 \mathrm{Cl}$ co-transport by the macula densa inhibits nitric oxide synthase activity. However, nitric oxide synthase requires calcium for enzyme activity [34, 35]. and it has been reported that perfusion of the macula densa with a low concentration of sodium chloride increases cytosolic free calcium concentration in macula densa cells [36]. Thus, it would be anticipated that $\mathrm{Na}^{+}-\mathrm{K}^{+}-2 \mathrm{Cl}$ - co-transport by the macula densa would decrease calcium concentration and suppress nitric oxide synthase activity. Although negative results have been obtained [36], 
frusemide has been reported to increase calcium levels in the kidney [37], and this would be expected to increase nitric oxide synthase activity. Our observation that frusemide increases NADPH diaphorase staining in the macula densa is consistent with such an action. Another problem is that, although some studies indicate that cyclic GMP stimulates renin secretion, others suggest that it inhibits or has no effect $[4,31,38-42]$.

It is important to acknowledge that, although our results are consistent with a role for nitric oxide in the macula densa control of renin secretion, they by no means prove it. It is possible, for example, that the action of L-NAME in suppressing the renin secretory response to frusemide results from blockade of nitric oxide synthesis in cells other than those of the macula densa, such as mesangial [43], endothelial or other cells. A systemic effect of LNAME also cannot be ruled out, although the present results suggest that changes in blood pressure are not responsible. Finally, even if the nitric oxide does originate in the macula densa, it may play a more generalized permissive or modulatory role rather than a mediator role. Nevertheless, the fact that there is abundant nitric oxide synthase in the macula densa together with our observation that the activity of this enzyme is apparently increased by frusemide warrants additional investigation of the role of the macula densa L-argininenitric oxide pathway in the regulation of renin secretion.

As has been observed by other investigators [29], frusemide elicited a transient increase in blood pressure and a prolonged increase in heart rate. Neither response appears to be due to the accompanying increase in renin secretion [29] but, beyond this, the mechanisms underlying these responses do not appear to have been identified. It was therefore of interest that, in the present study, blockade of nitric oxide synthesis inhibited the heart rate (but not the pressor) response to frusemide. This finding, together with evidence that implicates nitric oxide in the control of heart rate [44-47], suggests that nitric oxide participates in the heart rate response to frusemide.

\section{ACKNOWLEDGMENTS}

This research was supported by NIH Grant HL29714 and NASA Grant NAG 2-779. We thank Dina San Juan for measuring plasma renin activity, and Laura Nunes for performing the NADPH diaphorase histochemistry.

\section{REFERENCES}

I. Davis JO, Freeman RH. Mechanisms regulating renin release. Physiol Rev 1976; 56: I-56.

2. Keeton TK, Campbell WB. The pharmacologic alteration of renin release. Pharmacol Rev 1980; 32: 81-227.

3. Vander Af. Control of renin release. Physiol Rev 1967; 17: 359-82.
4. Hackenthal E, Paul M, Ganten D. Taugner R. Morphology, physiology, and molecular biology of renin secretion. Physiol Rev 1990; 70: $1067-116$.

5. Briggs. JP, Lorenz JN. Weihprecht $H_{1}$ Schnermann J. Macula densa control of renin secretion. Renal Physiol Biochem 1991; 14: 164-74.

6. Schlatter E, Salomonsson M. Persson AEG, Greger R. Macula densa cells sense luminal $\mathrm{NaCl}$ concentration via furosemide sensitive $\mathrm{Na}{ }^{+} \mathrm{Cl}^{-} \mathrm{K}^{+}$cotransport. Pflugers Arch 1989: 414: 286-90.

7. LaPointe $-Y$, Bell PD, Cardinal J. Direct evidence for apical $\mathrm{Na}^{+}: 2 \mathrm{Cl}^{-}: \mathrm{K}^{+}$ cotransport in macula densa cells. Am J Physiol 1990; 258: Fl 166-9.

B. Lorenz JN. Weihprecht H, Schnermann J, Skott O, Briggs JP. Renin release from isolated juxtaglomerular apparatus depends on macula densa chloride transport. Am J Physiol 1991: 260: F486-93.

9. Jackson EK. Adenosine: A physiological brake on renin release. Annu Rev Pharmacol Toxicol |99|; 3|: |-35.

10. Navar LG, Inscho EW, Ibarrola M, Carmines PK. Communication between the macula densa cells and the afferent arteriol. Kidney Int 1991; 39: 578-82.

II. Mundel P, Bachmann S, Bader $M$, et al. Expression of nitric oxide synthase in kidney macula densa cells. Kidney Int 1992: 12: 1017-19.

12. Wilcox CS, Welch W], Murad F, et al. Nitric oxide synthase in macula densa regulates glomerular capillary pressure. Proc Nati Acad Sci USA 1992; 89: $11993-7$.

13. Tojo A, Gross SS, Zhang L, et al. Immunocytochemical localization of distinct isolorms of nitric oxide synthase in the juxtaglomerular apparatus of normal rat kidney. J Am Soc Nephrol 1994; 4: 1438-47.

14. Goyer M, Bui H, Chou L, Evans ], Keil LC, Reid IA. Effect of inhibition of nitric oxide synthesis on vasopressin secretion in conscious rabbits. Am J Physiol 1994; 266: H822-B.

15. Kurtz A, Kaissling B, Busse R, Baier W. Endochelial cells modulate renin secretion from isolated mouse juxtaglomerular cells. I Clin Invest 1991; 88: $1147-54$.

16. Beierwaltes WH, Carretero OA. Nonprostanoid endothelium-derived factors inhibit renin release. Hypertension 1992; 19: 11-68-73.

17. Gardes J, Poux 1-M, Gonzalez M-F, Alhenc-Gelas F, Menard J. Decreased renin release and constant kallikrein secretion alter injection of L-Name in isolated perfused rat kidney. Life Sci 1992; 50: 987-93.

18. Johnson RA, Freeman RH. Pressure natriuresis in rats during blockade of the L-arginine/nitric oxide pathway. Hypertension 1992; 19: 333-8.

19. Sigmon DH, Carretero OA, Beierwaltes WH. Endothelium-derived relaxing factor regulates renin release in vivo. Am J Physiol 1992; 263: F256-61.

20. Chen M. Schnermann J. Malvin RL, Killen PD, Briggs JP. Time course of stimulation of renal renin messenger RNA by furosemide. Hypertension 1993: 21: $36-41$.

21. Itoh S, Carretero OA. Role of the macula densa in the control of renin release. Hypertension 1985; 7 : 1 -49-1-54.

22. Moncada S. Palmer RMJ, Higgs EA. Nitric oxide: physiology, pathophysiology, and pharmacology. Pharmacol Rey 1991; 43: 109-42.

23. Rees DD, Palmer RM], Schulz R. Hodson HF, Moncada S. Characterization of three inhibitors of endothelial nitric oxide synthase in vitro and in vivo. $\mathrm{Br} J$ Pharmacol 1990; 101: 746-52.

24. Menard J. Catt K]. Measurement of renin activity, concentration and substrate in rat plasma by radioimmunoassay of angiotensin I. Endocrinology 1972; 90: 422-30.

25. Glantz SA, Slinker BK. Primer of applied regression and analysis of variance. New York: McGraw-Hill, 1990.

26. Meyer $P$. Menard J, Papanicolaou N. Alexandre J-M. Devaux $C$. Milliez $P$. Mechanism of renin release following furosemide diuresis in the rabbit. Am I Physiol 1968; 215: 908-15.

27. Ganong WF. Sympathetic effects on renin secretion; mechanism and physiological role. In: Assaykeen TA, ed. Control of renin secretion. New York: Plenum, 1972: 17-32.

28. Petersen JS, DiBona GF. Reflex control of renal sympathetic nerve activity during furosemide diuresis in rats. Am J Physiol 1994; 226: R537-45.

29. Ueno $Y$, Arita $M$, Suruda $H$, et al. The effect of angiotensin II antagonist, Sar', ${ } \mathrm{Ie}^{\mathbf{0}}$ angiotensin $\mathrm{I}$ on furosemide induced increase in plasma noradrenaline, renin activity and aldosterone in unanesthetized dogs. Jpn Circ J 1980: 44: $981-7$

30. Johns E], Singer B. Effect of propranolol and theophylline on renin release caused by furosemide in the cat. Eur I Pharmacol 1973; 23: 67-73.

31. Skott $O$, Jensen BL. Cellular and intrarenal control of renin secretion. Clin Sci 1993: 84: $1-10$

32. Siragy HM. Endothelium-derived relaxing factor modulates renal interstitial cyclic GMP. I Cardioyasc Pharmacol 1992; 20: S163-5.

33. He X-R, Greenberg SG, Schnermann |B, Briggs JP. Role of nitric oxide (NO) in reguiation of macula densa mediated renin secretion. FASEB | 1993; 7: A221. 
34. Mayer B, Klatt P. Bohme E, Schmidt K. Regulation of neuronal nitric oxide and cyclic GMP formation by $\mathrm{Ca}^{2+}$. I Neurochem 1992; 59: 2024-9.

35. Bredt DS, Snyder SH. Nitric oxide, a novel neuronal messenger. Neuron 1991; 8: 3-11.

36. Salomonsson M, Gonzalez E, Westerlund P. Persson AE. Intracellutar cytosolic free calcium concentration in the macula densa and in ascending limb cells at different luminal concentrations of sodium chloride and with added furosemide. Acta Physiol Scand 1991; 142: 283-90.

37. Tsao PW, Klip A, Radde IC. Furosemide increases total calcium in the kidney and cytoplasmic free calcium in blood mononuclear cells of guinea pigs. Bio Neonate 1990; 57: 250-6.

38. Henrich WL, McAllister EA, Smith PB, Campbell WB. Guanosine 3',5-cyclic monophosphate as a mediator of inhibition of renin release. Am J Physiol 1988; 255: $5474-8$.

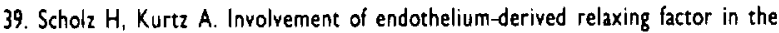
pressure control of renin secretion from isolated perfused kidney. I Clin Invest 1993: 91: 1088-94.

40. Peart WP, Quesada T, Tenyi I. The effects of cyclic adenosine $3^{\prime}, 5^{\prime}$-monophosphate and guanosine $3^{\prime}, 5^{\prime}$-monophosphate and theophylline on renin secretion in the isolated perfused kidney of the rat. $\mathrm{Br}$ / Pharmacol 1975; 54: 55-60.
41. Devlin AM, Leckie B]. Second messengers involved in the control of renin secretion in cultured human nephroblastoma cells. Am J Physiol 1994; 266: F667-73

42. Noble AR, Abu-Kishk RA, D'Aloia M-AE, Williams BC, Lush D Cyclic GMP-linked pathway for renin secretion. Kidney Int 1994; 46: 1588-90.

43. Tsukahara $H$, Krivenka Y, Moore LC, Goligorsky MS. Decrease in ambient $[\mathrm{Cl}-]$ stimulates nitric oxide release from cultured rat mesangial cells. Am I Physiol 1994; 267: Fi90-5.

44. Reid $\mid A$, Bui $H$. Chou $L$. Role of nitric oxide in the renin and heart rate responses to beta adrenergic stimulation. Hypertension 1994; 23 (Suppl. l): $1-49-53$.

45. Klimaschewski L, Kummer W. Mayer B, et al. Nitric oxide synthase in cardiac nerve fibers and neurons of rat and guinea pig heart. Circ Res 1992; 71: $1533-7$.

46. Klabunde RE, Ritger RC. Helgren MC. Cardiovascular actions of inhibitors of endothelium-derived relaxing factor (nitric oxide) formation/release in anesthetized dogs. Eur | Pharmacol 1991; 199: 51-9.

47. Han $X$. Shimoni $Y$, Giles WR. An obligatory role for nitric oxide in autonomic control of mammalian heart rate. | Physiol (London) 1994; 176: $309-14$ 
